\title{
Pacific herring spawn events influence nearshore subtidal and intertidal species
}

\author{
C. H. Fox ${ }^{1,2,4, *}$, P. C. Paquet ${ }^{2,3}$, T. E. Reimchen ${ }^{1}$ \\ ${ }^{1}$ Department of Biology, University of Victoria, Victoria, BC V8W 2Y2, Canada \\ ${ }^{2}$ Raincoast Conservation Foundation, Sidney, BC V8L 3Y3, Canada \\ ${ }^{3}$ Department of Geography, University of Victoria, Victoria, BC V8W 2Y2, Canada \\ ${ }^{4}$ Present address: Department of Oceanography, Dalhousie University, Halifax, NS B3H 4R2, Canada
}

\begin{abstract}
As intermediaries between the bottom and top of food webs, forage fish fuel a diversity of coastal consumers and are of socioecological importance throughout the world's oceans. Many forage fish are migratory, but despite their recognized importance, relatively little is known about their role in providing spatial subsidies, which are the movements of energy, material, and organisms across ecosystems. Until recently, spatial subsidies associated with Pacific herring Clupea pallasii, a dominant migratory forage fish that spawns in subtidal and intertidal zones, received little scrutiny. Building on research that traced links between herring spawns and coastal ecosystems, we used stable isotopes of carbon $\left(\delta^{13} \mathrm{C}\right)$ and nitrogen $\left(\delta^{15} \mathrm{~N}\right)$ to assess whether herring spawning events influenced isotopic signatures of 10 macrophyte and invertebrate species across beaches where spawning did or did not occur. Overall, species collected from spawning beaches had significantly greater $\delta^{15} \mathrm{~N}$ levels (general linear mixed model parameter estimate $=1.58 \pm$ $0.17 \mathrm{SE}, F_{1,370}=83.77, \mathrm{p}<0.001$ ); no significant effects were detected for $\delta^{13} \mathrm{C}$ (parameter estimate $\left.=0.03 \pm 0.23 \mathrm{SE}, F_{1,343}=0.01, \mathrm{p}=0.914\right)$. In terms of total nitrogen, macrophytes from spawning beaches had significantly elevated concentrations (parameter estimate $=5.03 \pm 0.94 \mathrm{SE}, F_{1,180}=$ $28.71, \mathrm{p}<0.001$ ). Using directional statistics, mean angles of isotopic change differed significantly between species collected from spawning and non-spawning beaches (Watson-Williams F-test; $F_{1,48}=10.44, \mathrm{p}=0.002$ ). Our study identifies multiple species as recipients of herring-derived nutrients at spawning events, providing additional evidence of the broad ecological influence of Pacific herring.
\end{abstract}

KEY WORDS: Clupea pallasii - Spatial subsidy - Stable isotopes · Forage fish $\cdot$ Invertebrates · Macrophytes $\cdot$ Intertidal $\cdot$ Subtidal

\section{INTRODUCTION}

Acting as the main intermediary between plankton near the base of the food web and a diversity of upper trophic level predators, forage fish fuel many marine ecosystems (Pikitch et al. 2012, 2014). They also represent the largest component of vertebrate biomass in marine ecosystems by weight and number (Pikitch et al. 2012), and account for roughly a third of wild fish catches worldwide (Smith et al. 2011, Pikitch et al. 2012). Due to the effects of commercial harvesting

${ }^{*}$ Corresponding author: carolinehfox@gmail.com and other drivers (e.g. disease, predation pressure, climate change), many forage fish have suffered depletions, with adverse impacts to a diversity of upper trophic level taxa (e.g. seabirds, Jahncke et al. 2004, Cury et al. 2011; marine mammals, Smith et al. 2011). However, many of the ecological consequences of forage fish depletions remain implied or unknown, largely due to a lack of information regarding forage fish relationships with other ecosystem components.

The substantial mobile biomass of migratory forage fish suggests that these fishes contribute to spatial

(C) The authors 2018. Open Access under Creative Commons by Attribution Licence. Use, distribution and reproduction are unrestricted. Authors and original publication must be credited. 
subsidies, which are the bi-directional flows of energy, material, and organisms across ecosystems (Polis et al. 1997). Despite several decades of sustained scientific research on spatial subsidies, studies of forage fish-derived spatial subsidies are relatively few in number. Although limited, evidence of the likely under-recognized role of forage fish in driving influential spatial subsidies is convincing; among the most prominent examples are the migratory movements of Norwegian spring-spawning Atlantic herring Clupea harengus, which is currently the largest known single-population biological flux of energy on the planet (Varpe et al. 2005). Western Baltic springspawning $C$. harengus, whose feeding grounds are in the North Sea, provide a spatial subsidy of lipids to a resident population of Atlantic cod Gadus morhua at the entrance to the Baltic Sea (van Deurs et al. 2016). Similar to Atlantic herring, Barents Sea capelin Mallotus villosus also transport substantial biomass and energy from offshore to coastal ecosystems (Røttingen 1990), and anadromous forage fish transport biomass and energy from marine ecosystems into freshwater and terrestrial ecosystems (e.g. Alosa spp., Garman \& Macko 1998, Dalton et al. 2009, Walters et al. 2009).

Although driven by abiotic and biotic processes, spatial subsidies associated with certain animal migrants have received considerable attention, including the migration of anadromous salmon (Oncorhynchus spp.) into freshwater and terrestrial ecosystems along the Pacific coast of North America. For receiving ecosystems, the ecological consequences of salmonderived energy and nutrients include shifts in productivity, biodiversity, and trophic interactions (e.g. Mathewson et al. 2003, Darimont et al. 2008, Hocking \& Reynolds 2011, Reimchen \& Fox 2013). The subsidy is also trophically broad, and multiple pathways into freshwater and terrestrial ecosystems have been identified (Cederholm et al. 1999, Reimchen 2018), ranging from primary producers (Reimchen et al. 2003, Janetski et al. 2009), invertebrates (Reimchen et al. 2003, Verspoor et al. 2011), small mammals (Ben-David et al. 1997), and songbirds (Christie \& Reimchen 2008), to upper trophic level predators and scavengers, including bears (Ursus spp., Reimchen 2000), grey wolves Canis lupus (Darimont et al. 2003), and bald eagles Haliaeetus leucocephalus (Restani et al. 2000). Despite the scientific attention given to spatial subsidies driven by salmon, these processes are embedded within ecosystems characterized by a diversity of other spatial subsidies, including those driven by migratory forage fish; knowledge of salmon spatial subsidies can be used to inform exploration of lesser-known interactions involving forage fish and other migrants.

Pacific salmon and forage fish are inextricably directly and indirectly connected via complex food webs and overlapping habitats. Of the diversity of migratory forage fish in coastal Pacific waters, Pacific herring C. pallasii play a pivotal ecological role as a cornerstone (Willson et al. 1998) and foundation species (sensu Soulé et al. 2003) in the marine ecosystems where they occur, which range from the coastal waters of California (USA), north through the Bering Sea, and south to China. Herring are also of profound social, cultural, and economic importance; as key examples, herring are a cultural keystone species to coastal Indigenous peoples (e.g. Thornton \& Kitka 2015, Moss 2016) and have been the target of substantial commercial fisheries (e.g. Taylor 1964, Hay et al. 2001), with particularly heavy exploitation throughout much of the 19th century. However, recent (e.g. Schweigert et al. 2010), historical (e.g. Hay et al. 2001), and deep time (e.g. McKechnie et al. 2014) herring declines and/or potential range contractions have been documented. Despite the importance of Pacific herring, the ecological consequences of these declines remain poorly understood. Further, as a migratory fish with seasonal movements that result in the transportation of energy and biomass from offshore waters (summer foraging grounds near the continental shelf break) to the coastal zone (nearshore wintering and spawning grounds), the crossecosystem consequences of Pacific herring are similarly not well understood from scientific perspectives.

Gathering in often immense concentrations, iteroparous Pacific herring spawn in nearshore subtidal and intertidal zones. During spawning, male Pacific herring broadcast milt in the nearshore and females lay adhesive eggs on a variety of nearshore and intertidal substrates, particularly macrophytes (e.g. giant kelp Macrocystis pyrifera, seagrasses [Zostera spp. and Phyllospadix spp.]), but also rock, woody debris, and other substrates (e.g. Haegele et al. 1981). Depending on environmental conditions and other factors, milt is often rapidly advected away from the initial release site. Eggs, which hatch within 2 to $3 \mathrm{wk}$ (Alderdice \& Velsen 1971, Bishop \& Green 2001), often experience substantial losses due to predation, anoxia, wave action, transportation away from the spawning site, and other mechanisms (Haegele \& Schweigert 1985, Shelton et al. 2014, Keeling et al. 2017). Following the hatch period, dead, rotting eggs and egg casings may persist in and near spawning sites for several weeks (Fox 2013). In certain areas, windrows of dead eggs and egg casings generated 
by wave and tidal action persist in intertidal, supratidal (C.H. Fox pers. obs.), and likely nearshore subtidal zones. As such, there are somewhat prolonged opportunities for large quantities of herring-derived nutrients to enter nearshore, intertidal, and terrestrial food webs, with the possibility of uptake by macrophytes and other primary producers (e.g. phytoplankton), in addition to consumption of herring eggs by a diversity of coastal consumers.

Pacific herring spawning events attract significant aggregations of coastal predators and scavengers, including a diversity of marine and terrestrial vertebrates (Willson \& Womble 2006, Fox 2013, Fox et al. 2015). Invertebrate taxa in nearshore marine and intertidal zones have also been linked to herring spawns (e.g. Purcell 1989, Fox et al. 2014). As part of a broader study of interactions between Pacific herring spawning events and nearshore marine, intertidal, and terrestrial ecosystems, intertidal/supratidal amphipods (Traskorchestia spp.) were identified as likely candidates for interaction, largely due to their co-occurrence with herring eggs in intertidal wrack lines and their detritivorous nature. In the postspawn period, amphipods had significantly altered isotopic signatures of nitrogen $\left(\delta^{15} \mathrm{~N}\right)$ and carbon $\left(\delta^{13} \mathrm{C}\right)$, and elevated concentrations of docosahexaenoic acid (DHA) and eicosapentaenoic acid (EPA), in comparison with amphipods at spawn-free locations (Fox et al. 2014). These differences were attributed to herring, particularly their eggs (Fox et al. 2014).

Using this dual evidence of a herring subsidy to Traskorchestia spp. amphipods, which are a dominant invertebrate in many high intertidal and supratidal zones in the region, we expanded our study to include macrophyte and invertebrate species across multiple trophic levels in nearshore subtidal and intertidal zones, with a focus on $\delta^{13} \mathrm{C}$ and $\delta^{15} \mathrm{~N}$. Across herring spawn and spawn-free beaches in Quatsino Sound, on Canada's Pacific coast, stable isotope samples from 10 species of primary producers (macrophyte algae and seagrass), and grazer, detritivore, and carnivore invertebrates that inhabit nearshore subtidal and intertidal zones were collected before and after herring spawning events. To test whether herring spawns influence nearshore and intertidal communities, we used $\delta^{15} \mathrm{~N}$ and $\delta^{13} \mathrm{C}$ in macrophyte and invertebrate tissues as indicators. Patterns of total nitrogen in macrophyte species, in periods before and after herring spawning, were also evaluated. Lastly, we used directional (circular) statistics to test whether invertebrates and macrophytes on spawning beaches differed isotopically from those collected from beaches without spawning, using $\delta^{15} \mathrm{~N}$ and $\delta^{13} \mathrm{C}$ to quantify directional change.

\section{MATERIALS AND METHODS}

Quatsino Sound, located off northwestern Vancouver Island, British Columbia (BC), Canada, was chosen as a study area due to the presence of somewhat undisturbed coastal ecosystems and a reliable but relatively small (i.e. 1000 t adult spawning biomass; Fisheries and Oceans Canada 2012) annual Pacific herring spawn that occurs in nearshore and intertidal zones. Although herring spawn regularly in the Forward Inlet area of Quatsino Sound each year, their use of individual beaches is somewhat unpredictable; we therefore collected stable isotope samples from organisms at multiple beaches before the spawn and at select beaches following the spawn to allow for within and between beach comparisons of $\delta^{15} \mathrm{~N}$ and $\delta^{13} \mathrm{C}$ signatures, including spawn-free control beaches.

Pacific herring spawning began at study sites in the Forward Inlet of Quatsino Sound on 22 March 2011 and 1 April 2012. During repeat visits to the study beaches throughout March and April (2011-2012), the occurrence of spawning was verified by the presence of milt (sperm), spawning adult herring, and/or herring eggs attached or loose on nearshore and intertidal substrates (e.g. on blades of giant kelp Macrocystis pyrifera, loose eggs in wrack lines). Over the 2 yr study period, 5 beaches were sampled before and following the herring spawn (Fig. 1). In 2011, our study sites consisted of $100 \mathrm{~m}$ wide sections at each of 3 spawning and 2 control beaches. In 2012, the pattern of herring spawning shifted, and study sites comprised 1 spawning and 1 control beach (same 2 beaches as in 2011). All but 1 beach were exposed to open-ocean swell with large M. pyrifera forests in the nearshore. Descriptions of beach substrates, in situ productivity, and wrack loading are provided in more detail by Fox et al. (2014).

\section{Stable isotope sampling}

Stable isotope samples were collected from 5 macrophyte, 5 invertebrate, and 1 vertebrate species (herring eggs) from the nearshore subtidal through to the high intertidal zone. Depending on the species, samples collected before and after the herring spawn were from the same restricted $\sim 1 \mathrm{~m}$ tidal height width which represented the highest densities of those spe- 


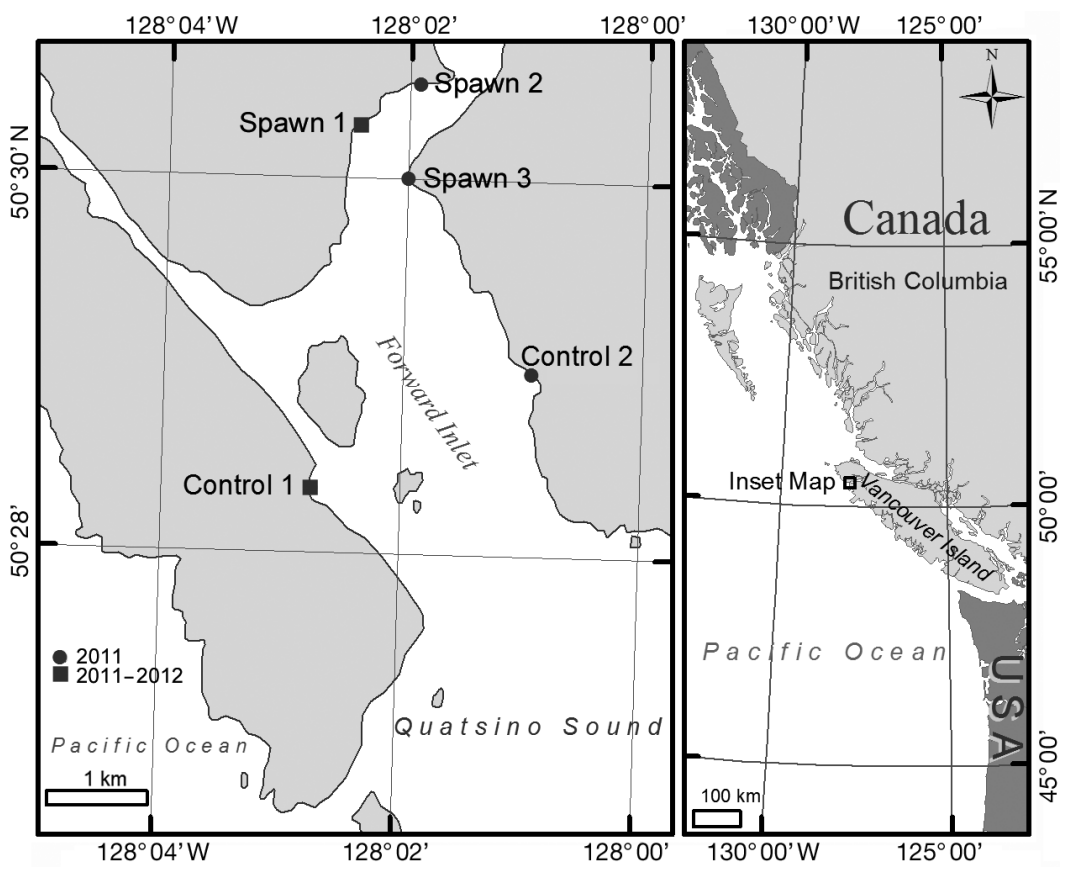

Fig. 1. Locations of beaches on which Pacific herring Clupea pallasii spawn, and spawn-free control beaches in Quatsino Sound, British Columbia, Canada, that were used in this study in 2011 and 2012 growth patterns (e.g. tissues near the meristem of $M$. pyrifera blades) and often, the lack of epiphytic growth on newer tissues (e.g. older blades of $M$. pyrifera are often heavily fouled). For sampled invertebrates, new biomass and catabolic tissue replacement influence isotopic incorporation, with growth anticipated to dominate in small, rapidly growing animals and catabolic turnover in slower-growing animals (Vander Zanden et al. 2015). Although rates of invertebrate isotopic turnover vary (Vander Zanden et al. 2015), estimates of 3 invertebrate species' half-lives (time for $50 \%$ isotopic dilution) ranged from 4 to 19 d (Fry \& Arnold 1982), which falls near the range of our sampling intervals. Further, an earlier study (Fox et al. 2014) demonstrated the utility of sampling amphipods (Traskorchestia spp.) following the main egg hatch period for the purposes of detecting herring-derived stable isotopes.

cies within a given beach site. Although not all species were available at all beaches, species were only included in the study when samples could be collected before and after the spawn event at both a control beach and a beach where spawning occurred in the same year. Stable isotope samples were collected before and after the Pacific herring spawn in 2011 (7, 8, 13, 16, 17, 20 March and 11-13, 15, 16 April) and 2012 (10, 12 March and 22, 24 April), with the exception of the eggs of Pacific herring, which were collected from 2 beaches in 2011 (29 March) and 2012 (7 April). All samples, including herring eggs, were collected by hand; the majority were collected from intertidal zones, but some species were collected by wading into shallow subtidal zones or from a boat (i.e. emergent blades of $M$. pyrifera).

Sampling dates post-spawn were largely determined by weather restrictions and the intent to sample in the days following the main egg hatching period ( 2 to 3 wk post spawn). With regard to macrophyte and invertebrate tissue incorporation of isotopes, whether herring-derived or otherwise, 2 processes are involved: growth (new biomass) and catabolic tissue replacement (Fry \& Arnold 1982). For macrophytes, newer tissues were sampled in the periods before and after the spawn in order to capture recent nutrient sources. New tissues were readily identified for macrophyte species based on
Tissues from live, intact attached macrophytes growing in the nearshore and intertidal were collected, with 3 blades from 3 adjacent plants constituting 1 sample $(\mathrm{n}=5$ samples from each beach in each sampling period). Five macrophyte species were collected: the seagrass Phyllospadix serrulatus, giant kelp M. pyrifera, rockweed (Fucus spp.), red fir (Callithamnion spp.), and sea lettuce Ulva lactuca. Five invertebrate species were collected: 2 whelk snails (Nucella lamellosa and $N$. ostrina), rock limpet Tectura persona, and 2 beach amphipods (Traskorchestia georgiana and T. traskiana). The 2 amphipod species were combined for stable isotope analysis as they are not readily distinguishable without preservation and microscopy. For all invertebrate species, depending on organism size, single to multiple individuals were pooled per sample $(\mathrm{n}=5$ samples beach $^{-1}$ in each sampling period, except $T$. georgiana and $T$. traskiana, $\mathrm{n}=10$ beach $^{-1}$, due to an associated study; Fox et al. 2014).

After collection, all samples were kept cool during 1-2 $\mathrm{h}$ of transport before processing. Macrophyte samples were scraped with a razor blade (if bladelike) or combed with tweezers (if foliose) to remove epiphytes. All macrophyte and invertebrate samples were subsequently rinsed with distilled water and frozen at $-20^{\circ} \mathrm{C}$ until further processing in the lab. Shelled invertebrates were also processed identical 
to other samples, but were later de-shelled in the lab using forceps.

Samples were dried for $48 \mathrm{~h}$ at $60^{\circ} \mathrm{C}$ and subsequently ground into a fine powder using a Wig-LBug amalgamator. Subsamples (1 to $3 \mathrm{mg}$, depending on $\mathrm{N}$ and $\mathrm{C}$ content) were packaged in tin capsules and analyzed for elemental and isotopic composition of nitrogen and carbon at the University of California Davis Stable Isotope Facility using a PDZ Europa ANCA-GSL elemental analyzer interfaced to a PDZ Europa 20-20 isotope ratio mass spectrophotometer (Sercon). Natural abundances of ${ }^{15} \mathrm{~N}\left(\delta^{15} \mathrm{~N}\right)$ and ${ }^{13} \mathrm{C}$ $\left(\delta^{13} \mathrm{C}\right)$ are expressed as deviation from standards (atmospheric $\mathrm{N}_{2}$ and Pee Dee Belemnite) in parts per thousand $(\%)$ calculated by $\left(R_{\text {sample }} / R_{\text {standard }}-1\right)$, where $R$ is the heavy:light isotopic ratio. Analytical error from replicated standards measured 0.1 SD (\%) for carbon and 0.2 SD (\%) for nitrogen. Post hoc lipid corrections were applied to $\delta^{13} \mathrm{C}$ animal tissue sample data (invertebrate samples and herring eggs) using $\mathrm{C}: \mathrm{N}$ ratios following recommendations for aquatic organisms by Post et al. (2007).

\section{Statistical analysis}

General linear mixed models (GLMMs) were separately constructed. To assess the influence of herring spawn on $\delta^{15} \mathrm{~N}$ and $\delta^{13} \mathrm{C}$ values of macrophyte and invertebrate species, we used $\delta^{15} \mathrm{~N}$ or $\delta^{13} \mathrm{C}$ as the response variable, with spawn presence/absence and time (pre and post spawn) as fixed factors, and beach location, species, and year as random effects. Similarly, to assess whether total nitrogen differed between macrophytes at spawn and spawn-free sites, we used total nitrogen in macrophyte tissues as the response variable, with the same fixed and random factors as the stable isotope models. Continuous dependent variables approached normality and were visually assessed for heteroscedasticity. Independent variables were binary or consisted of multiple categories (i.e. location). GLMMs were performed using SPSS v23 (IBM).

To examine isotopic shifts in $\delta^{15} \mathrm{~N}$ and $\delta^{13} \mathrm{C}$ combined, we used directional (circular) graphics and statistics, which involve the use of von Mises distributed angular data $\left(0^{\circ}\right.$ to $360^{\circ}$; Batschelet 1981 , Schmidt et al. 2007). Directional isotopic change was calculated by measuring the difference between means $\delta^{15} \mathrm{~N}$ ( $y$-axis) and $\delta^{13} \mathrm{C}$ ( $\mathrm{x}$-axis) before and after the spawning period; isotopic data were converted into mean angle (direction; $\theta$ ) and mean magnitude (length) of isotopic change for each species at each beach site and year. Plotted as arrows that represent time (before and after spawning), mean isotopic change was visually assessed for macrophyte and invertebrate species on beaches with and without spawning. A Watson-Williams F-test was used to test whether the mean angle of change for macrophyte and invertebrate species (per beach and year) differed based on whether beaches received herring spawn. We hypothesized (null) that mean angles for species collected from spawn and spawn-free beaches are the same. Directional statistics and graphics were completed in Oriana v4 (Kovach Computing Services).

\section{RESULTS}

In general, pronounced increases in macrophyte $\delta^{15} \mathrm{~N}$ were detected at many, but not all, beaches where Pacific herring spawned, in comparison to spawn-free spatial controls or pre-spawning temporal controls (Fig. 2A-E, and see Table S1 in the Supplement at www.int-res.com/articles/suppl/m595p157_ supp.pdf). With exception of the seagrass Phyllospadix serrulatus, macrophyte $\delta^{15} \mathrm{~N}$ at spawning beaches was substantially higher in the post spawn period than in controls, which tended to demonstrate moderate $\delta^{15} \mathrm{~N}$ increases or remain relatively constant. For example, $\delta^{15} \mathrm{~N}$ levels in Ulva lactuca were substantially higher on 2 beaches following the spawn $\left(\delta^{15} \mathrm{~N}=12.32 \%\right.$ and $12.73 \%$ ) , as opposed to those same beaches before the spawn and on control beaches $\left(\delta^{15} \mathrm{~N} \min =7.09 \%\right.$, $\delta^{15} \mathrm{~N} \max =8.04 \%$; Table S1). Patterns of $P$. serrulatus $\delta^{15} \mathrm{~N}$ differed from other macrophytes; control $\delta^{15} \mathrm{~N}$ was lower in the post spawning period, whereas samples from spawning beaches demonstrated increases or slight declines (Fig. 2A). In terms of invertebrate $\delta^{15} \mathrm{~N}$, amphipods (Traskorchestia spp.) demonstrated elevated values at spawning beaches in the post spawning period, relative to controls (Fig. 2F). This pattern of increase, however, was less pronounced than in the macrophytes. In addition, the limpet Tectura persona and the 2 whelk snails Nucella lamellosa and $N$. ostrina demonstrated more variable patterns of $\delta^{15} \mathrm{~N}$ change (Fig. 2G, H). Overall, the presence of herring spawn had a significant positive influence on $\delta^{15} \mathrm{~N}$ signatures of macrophytes and invertebrates (GLMM; parameter estimate $\left.=1.58 \pm 0.17 \mathrm{SE}, F_{1,370}=83.77, \mathrm{p}<0.001\right)$, but time (pre and post spawn) did not (GLMM; parameter estimate $=0.02 \pm 0.13, F_{1,506}=0.02, \mathrm{p}=0.883$; Table S2). Mean herring egg $\delta^{15} \mathrm{~N}$ was higher than all sampled invertebrates and macrophytes $(14.63 \pm 0.06 \%)$. 

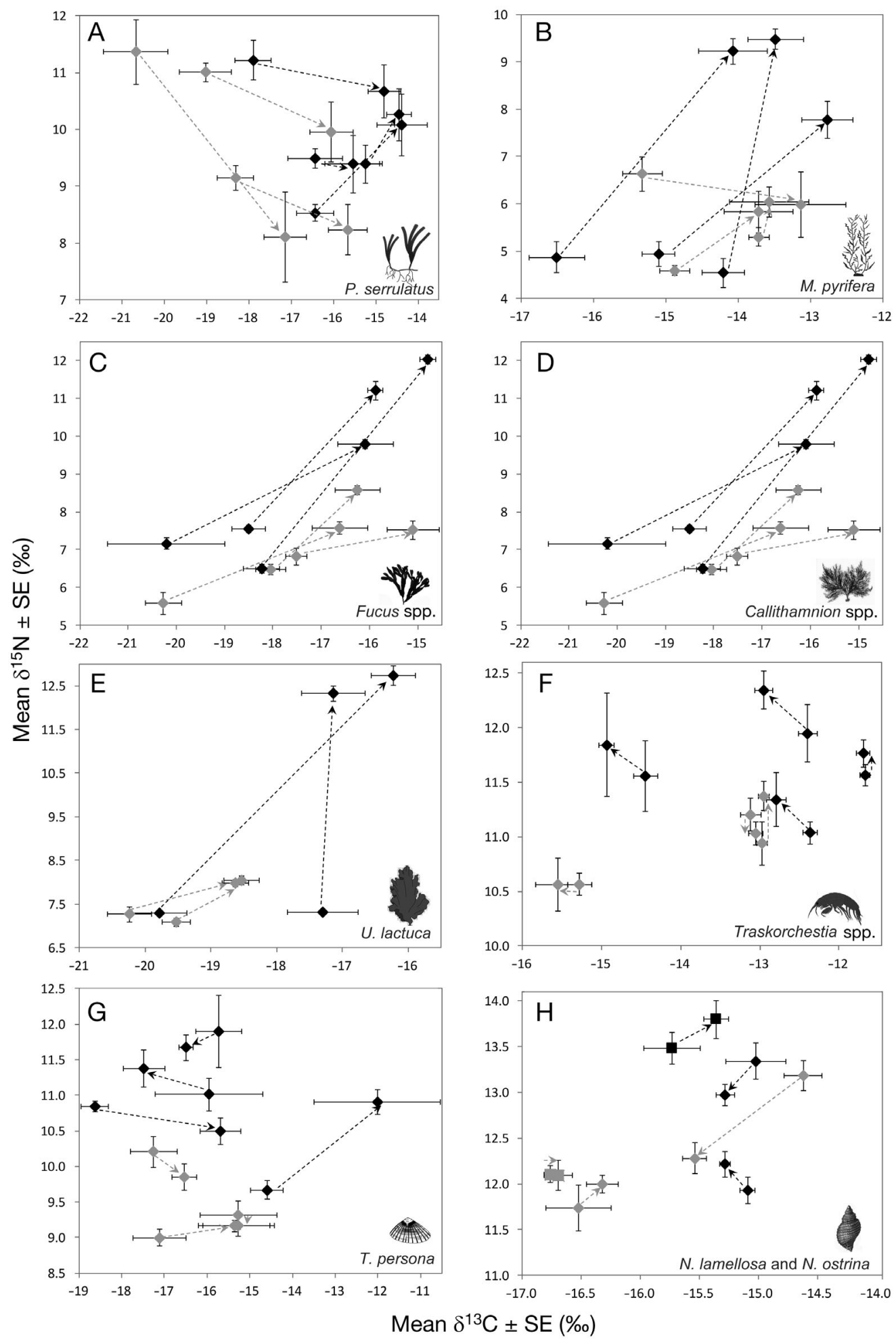

Fig. 2. Mean $\pm \mathrm{SE} \delta^{15} \mathrm{~N}(\%)$ and $\delta^{13} \mathrm{C}(\%)$ isotopic values for (A) Phyllospadix serrulatus, (B) Macrocystis pyrifera, (C) Fucus spp., (D) Callithamnion spp., (E) Ulva lactuca, (F) Traskorchestia spp., (G) Tectura persona, and (H) Nucella lamellosa (diamonds) and $N$. ostrina (squares) at study sites (beaches) in Quatsino Sound, British Columbia, in periods before and after Pacific herring Clupea pallasii spawning events. Control samples collected from non-spawning beaches (grey) are differentiated from samples collected from spawning beaches (black). Dashed line arrows indicate the directionality between samples collected from beaches before and after spawning. Not displayed above, Pacific herring egg isotopic values lie at mean $-18.35 \pm 0.03 \% \mathrm{SE}\left(\delta^{13} \mathrm{C}\right)$ and $14.63 \pm 0.06 \%$ o $\left(\delta^{15} \mathrm{~N}\right)$. Images from the IAN Image Library (ian.umces.edu) 
In terms of macrophyte $\delta^{13} \mathrm{C}$, the general trend across all beaches was of increasing $\delta^{13} \mathrm{C}$ with time (pre and post spawn); invertebrate $\delta^{13} \mathrm{C}$ was more variable (Fig. $2 \mathrm{~A}-\mathrm{H})$. Overall, time had a significant positive influence on macrophyte and invertebrate $\delta^{13} \mathrm{C}(\mathrm{GLMM}$; parameter estimate $=1.25 \pm 0.17 \mathrm{SE}$, $\left.F_{1,492}=52.92, \mathrm{p}<0.001\right)$. The presence of herring spawn did not significantly influence macrophyte and invertebrate $\delta^{13} \mathrm{C}(\mathrm{GLMM}$; parameter estimate $=$ $0.03 \pm 0.23, F_{1,343}=0.01, \mathrm{p}=0.914$; Table S2). Mean herring egg $\delta^{13} \mathrm{C}$ values fell within the ranges of most invertebrates and macrophytes, with the exception of M. pyrifera, Traskorchestia spp., N. ostrina, and N.
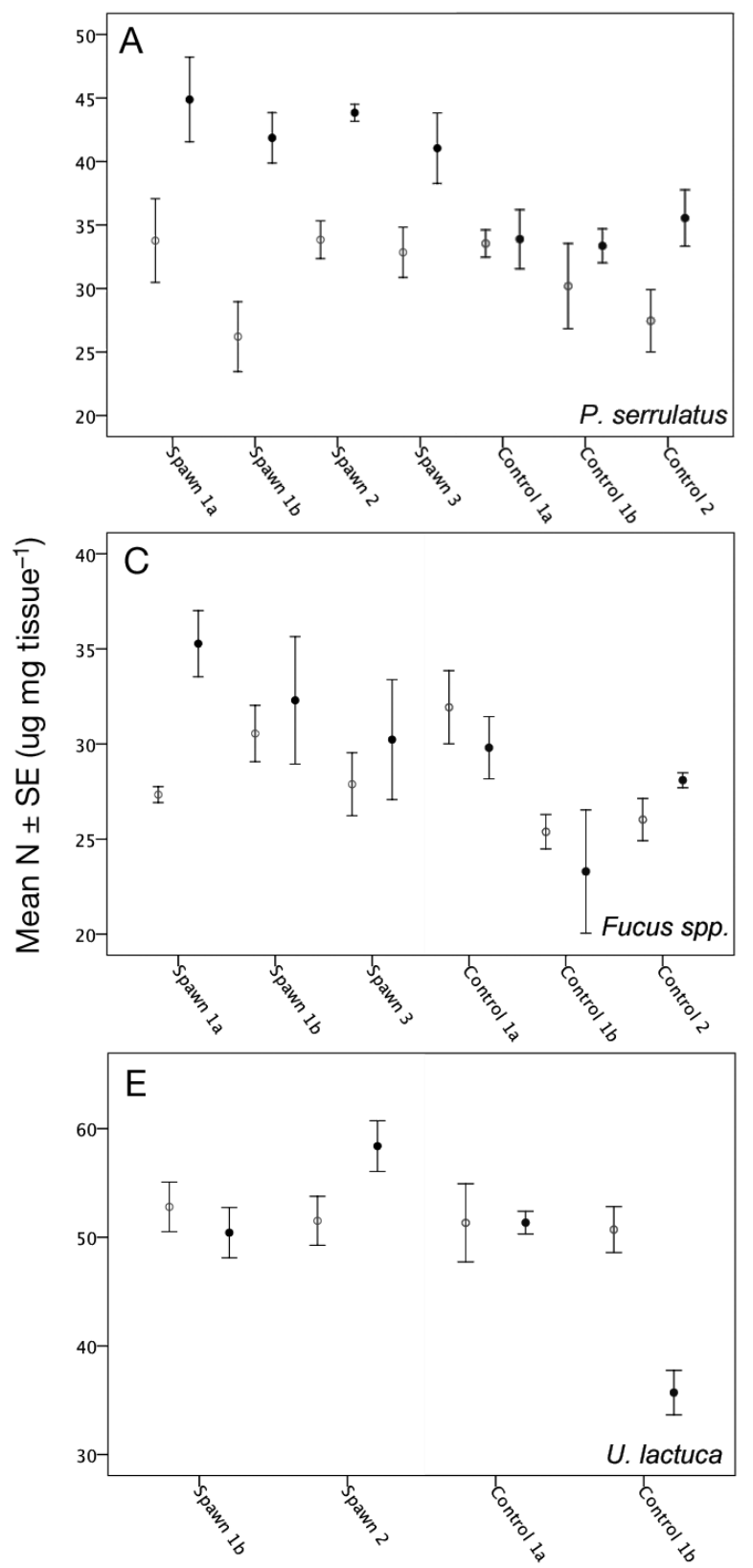

lamellosa, which were less depleted than herring eggs $(-18.35 \pm 0.03 \%$ )

Although variable on a location and species-specific basis (Fig. 3), total nitrogen ( $\mu \mathrm{g} \mathrm{N} \mathrm{mg}{ }^{-1}$ tissue) in macrophyte tissues significantly differed over time, with lower concentrations in the post spawning period $\left(\mathrm{GLMM}_{i}\right.$ parameter estimate $=-2.12 \pm 0.71 \mathrm{SE}, F_{1,265}=$ 8.86, $p=0.003$ ). However, for macrophytes sampled from beaches with herring spawn, significantly higher total nitrogen was detected (GLMM; parameter estimate $=5.03 \pm 0.94 \mathrm{SE}, F_{1,180}=28.71, \mathrm{p}<0.001$; Fig. 3).

Directional information (angle and length) calculated from macrophyte and invertebrate $\delta^{15} \mathrm{~N}$ and
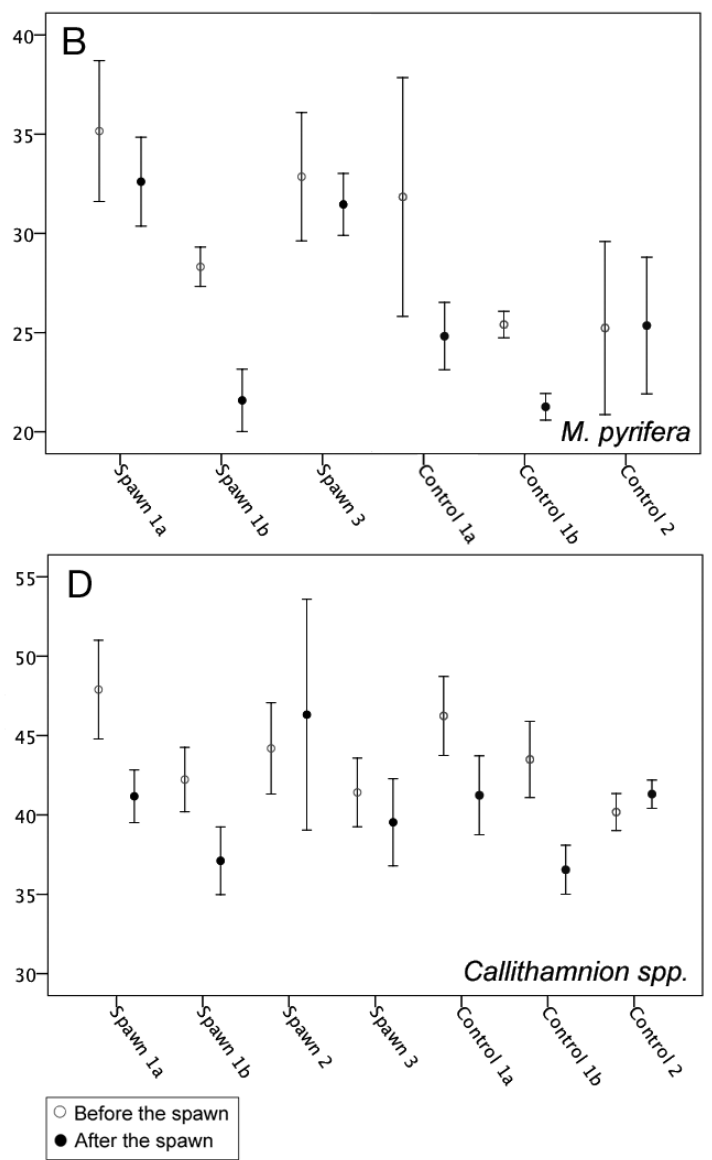

Fig. 3. Mean $\pm \mathrm{SE}$ total $\mathrm{N}\left(\mu \mathrm{g} \mathrm{mg}^{-1}\right.$ tissue) for the macrophytes (A) Phyllospadix serrulatus, (B) Macrocystis pyrifera, (C) Fucus spp., (D) Callithamnion spp., and (E) Ulva lactuca on beach study sites, where Pacific herring Clupea pallasii spawn (spawn beaches) and do not spawn (control beaches) in Quatsino Sound, British Columbia, in periods before (open circles) and after (closed circles) spawning events. For Spawn 1 and Control 1 sites, 'a' and 'b' refer to 2011 and 2012, respectively 
$\delta^{13} \mathrm{C}$ values before and after spawning was also examined. At spawn-free beaches, mean macrophyte species isotopic change was consistent for $\delta^{13} \mathrm{C}$, with all species shifting towards greater enrichment; variable $\delta^{15} \mathrm{~N}$ change (depletion and enrichment) was demonstrated (Fig. 4A). In contrast, macrophytes on spawning beaches all demonstrated a shift towards greater $\delta^{15} \mathrm{~N}$ and $\delta^{13} \mathrm{C}$ enrichment, with the largest mean shifts $(>4.0 \%$ ) observed in U. lactuca, M. pyrifera, and Fucus spp. (Fig. 4B). At spawn-free bea- ches, invertebrate species isotopic changes were similar, with species becoming slightly more $(<1.0 \%)$ depleted in $\delta^{13} \mathrm{C}$ and $\delta^{15} \mathrm{~N}$ over time (Fig. $4 \mathrm{C}$ ). Invertebrate isotopic change at spawning beaches was more variable, with isotopic changes occurring in all quadrants of isotopic space (Fig. 4D). The difference between mean angles for all species collected from spawning $(\mathrm{n}=27)$ and spawn-free $(\mathrm{n}=23)$ beaches was significant (Watson-Williams $F$-test; $F_{1,48}=10.44$, $\mathrm{p}=0.002)$.
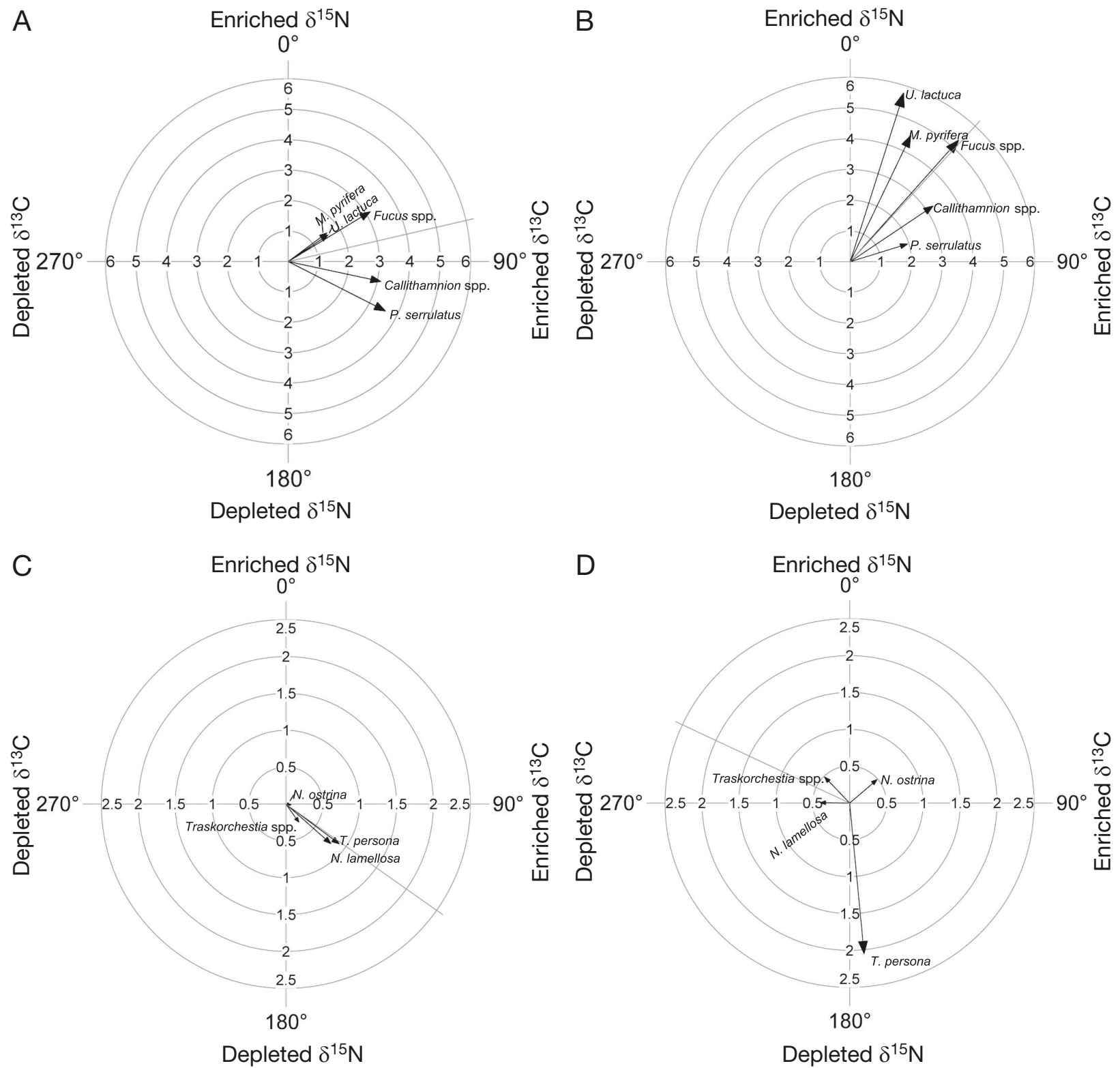

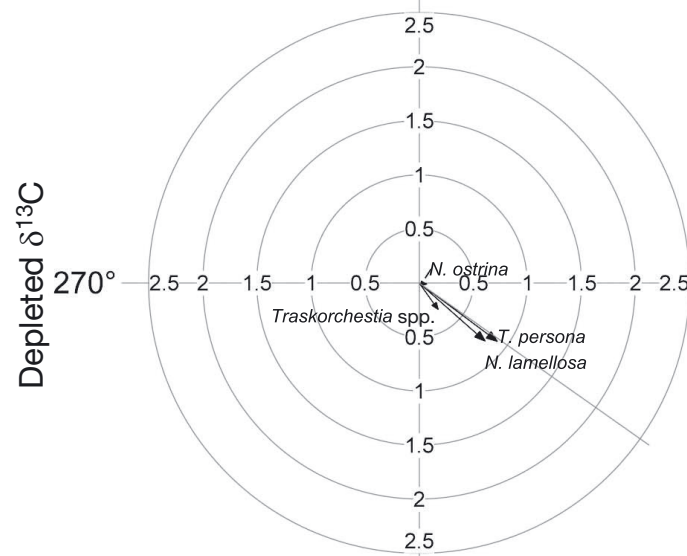

$180^{\circ}$

Depleted $\delta^{15} \mathrm{~N}$

Fig. 4. Mean directional isotopic change (length and angle) of macrophytes at (A) control and (B) spawning sites, and invertebrates at (C) control and (D) spawning sites relative to mean pre-spawn isotopic values using $\delta^{13} \mathrm{C}(\%)$ and $\delta^{15} \mathrm{~N}(\%)$. Arrows represent individual species or genera, averaged across multiple sites. Arrow length represents the magnitude of isotopic change $(\%)$. The grey line represents the mean vector of change $(\mu)$, indicating the mean angle of the data displayed in individual plots 


\section{DISCUSSION}

Involving a trophically broad, stable isotope-based examination of the influence of herring spawn in intertidal and nearshore subtidal ecosystems, our study builds on previous research that traced Pacific herring-derived lipids and stable isotopes of carbon and nitrogen into intertidal amphipods (Traskorchestia spp.; Fox et al. 2014), evaluated consumption of amphipods and herring eggs by American black bears (Ursus americanus; Fox et al. 2015), and documented beach-adjacent denning by black bears (Fox et al. 2010). Using an explicit design, with spatial and temporal controls, our study found that the presence of herring spawn resulted in significantly elevated macrophyte and invertebrate $\delta^{15} \mathrm{~N}$, with most pronounced effects detected in macrophytes. In contrast, the overall trend for macrophyte and invertebrate $\delta^{13} \mathrm{C}$ on both control and spawning beaches was an increase in the post spawning period, with no significant influence of herring spawn detected. For macrophytes, total nitrogen was generally lower in the post spawning period and although variable across species, was higher overall for macrophytes growing on spawning beaches. Using directional statistics, mean angles of isotopic change differed significantly between species collected from beaches with and without herring spawning. Overall, our study contributes evidence that herring-derived nutrients enter nearshore and intertidal foodwebs at multiple trophic levels, including primary producers and invertebrate consumers. Coupled with existing knowledge of linkages with terrestrial (e.g. black bear, grey wolf, and songbird consumption of herring eggs; Fox 2013, Fox et al. 2015, traditional and local knowledge holders), intertidal (Fox et al. 2014), and marine predators and scavengers (Willson \& Womble 2006), our research provides additional evidence regarding the broad, multi-trophic level ecological reach of spawning herring across coastal ecosystems. In the future, the evaluation of fatty acids (e.g. Fox et al. 2014) and potentially stable isotopes from targeted molecules (e.g. amino acids; Larsen et al. 2013) could provide additional opportunities to trace herring-derived nutrients through often isotopically variable (e.g. Foley \& Koch 2010) coastal ecosystems.

The isotopic signatures of herring eggs provide insight into our findings that relate to the significant influence of herring spawn on $\delta^{15} \mathrm{~N}$ values and the lack of influence on $\delta^{13} \mathrm{C}$ values of macrophytes and invertebrates. $\delta^{15} \mathrm{~N}$, which increases from producer to consumer, is used in many food web studies to estimate trophic level (DeNiro \& Epstein 1981, Mina- gawa \& Wada 1984); in studies of marine subsidies, however, $\delta^{15} \mathrm{~N}$ is often used as a tracer, with elevated $\delta^{15} \mathrm{~N}$ indicating marine contributions in receiving taxa (reviewed by Hobson 1999). In our study, herring egg $\delta^{15} \mathrm{~N}$ was higher than that in all macrophyte and invertebrate species sampled, which supports our use of $\delta^{15} \mathrm{~N}$ as an indicator of a herring spatial subsidy, and particularly so when coupled with evidence that $\delta^{15} \mathrm{~N}$ did not otherwise differ significantly over time. Often used as an indicator of carbon source due to the conservation of isotopic values across trophic levels (Rounick \& Winterbourn 1986, Peterson \& Fry 1987), herring egg $\delta^{13} \mathrm{C}$ values overlapped with the $\delta^{13} \mathrm{C}$ values of the majority of species, with the exception of 4 species (Macrocystis pyrifera, Traskorchestia spp., Nucella ostrina, and N. lamellosa). Further, often substantial shifts in $\delta^{13} \mathrm{C}$ values were detected in macrophytes and invertebrates at control and spawning beaches, with time having a significant overall effect. Due to this isotopic overlap between herring eggs and several receiving species, in addition to underlying natural dynamism, $\delta^{13} \mathrm{C}$ in this system does not appear to be a strong candidate for distinguishing herring spatial subsidies. However, our earlier research successfully used stable isotopes of carbon and nitrogen in conjunction with fatty acids to trace the contribution of herring resources to Traskorchestia spp. (Fox et al. 2014), one of the species that did not isotopically overlap with herring egg $\delta^{13} \mathrm{C}$ values, indicating that $\delta^{13} \mathrm{C}$ may provide insight for certain taxa.

Complementary to the bi-plots and separate GLMM analyses of $\delta^{15} \mathrm{~N}$ and $\delta^{13} \mathrm{C}$, directional statistics allowed for a combined examination of species' isotopic change (e.g. Schmidt et al. 2007) on beaches with and without spawning. Differences between macrophytes and invertebrates were more apparent in this analysis, with macrophytes on spawning beaches demonstrating often large isotopic shifts, whereas invertebrate isotopic change on spawning beaches was more variable. Both responses contrast with macrophyte and invertebrate isotopic change on control beaches, where relatively consistent and often more subtle directional shifts were detected. Mean angles of isotopic change were significantly different between spawning and spawn-free beaches, which further indicates community-level isotopic shifts linked to herring spawning events.

In addition to elevated $\delta^{15} \mathrm{~N}$, total nitrogen in macrophytes was significantly higher on spawning beaches. Although macroalgal productivity is largely controlled by light and nutrient availability (Fujita et al. 1989), in addition to other factors (e.g. water 
movement; Hepburn et al. 2007), the shift from low light winter conditions occurs in early spring, whereas nutrient limitation occurs sporadically in upwelling regions along the Pacific coast of North America (e.g. Fujita et al. 1989). While nutrient conditions were not known for the study sites in Quatsino Sound, study timing coincided with the onset of vigorous growth for the macrophytes and the development of often thick intertidal biofilm available to grazers (C.H. Fox pers. obs.). Nutrient limited or not, herring spawning events provide a pulse of nutrients to nearshore macrophytes, many of which are capable of storing nitrogen for extended periods (e.g. Macrocystis pyrifera; Zimmerman \& Robertson 1985). Given the variable timing and locations of herring spawning events along the coasts of North America and Asia, spawning undoubtedly occurs under a range of conditions; the role and ecological influence of herring-derived nutrients on macrophytes is also anticipated to vary, including potential effects on primary production. As an example from an oligotrophic system, extensive beds of Saccharina spp. once grew along the west coast of Hokkaido, Japan, but no longer form due to nutrient limitations (Kuribayashi et al. 2017). Using $\delta^{15} \mathrm{~N}$ from $>100 \mathrm{yr}$ old herbarium specimens, Kuribayashi et al. (2017) found evidence that spawning Pacific herring had potentially contributed significant amounts of nitrogen to Saccharina spp., with historical herring catches of \%60 000 t (1880-1920) representing 500-1000 times the size of catches in recent years.

Spawning herring provide a pulsed, often superabundant resource (e.g. Yang et al. 2008) to coastal ecosystems. While access to herring-derived nutrients for macrophytes and other primary producers is via dissolved inorganic nutrients released by microbial degradation processes and other mechanisms, detritivores, scavengers, and predators exploit valuable carbon- and nitrogen-rich biomolecules such as lipids and amino acids via consumption of herring and their eggs. Because herring eggs are a source of valuable essential fatty acids (EFAs) such as EPA and DHA (Huynh et al. 2007, Fox et al. 2014) and essential amino acids (Iwasaki \& Harada 1985), these biomolecules are not only redistributed throughout nearshore marine food webs but intertidal and terrestrial food webs as well via predators, scavengers, and detritivores (e.g. Fox et al. 2014, 2015). With regard to EFA redistribution throughout marine food webs, such spawning events have been described as an 'egg boon' (Fuiman et al. 2015); in the case of spawning herring, the consequences of this pulsed resource extend beyond marine ecosystems.
As a pulsed resource, herring spawning events also come with a significant temporal lag. Increasing in length and mass, and sequestering valuable lipids (e.g. Hart et al. 1940, Huynh et al. 2007) in productive coastal waters during the previous summer and fall, herring fast or feed negligibly throughout the winter (Wailes 1936). With most Pacific herring spawning occurring from February to April in BC, this pulsed delivery of spawn resources consists of biomass, nutrients, and energy gained in seasonally productive coastal waters during the previous year. Arriving at a time when alternative resources are relatively low, this pulsed delivery offers delayed access to the products of primary production in a seasonally variable upwelling system via a forage fish. Elsewhere along the Pacific coast of North America, spawn timing varies, with spawning events generally beginning during winter in California and spreading north along the coast to finish in Alaska in summer, a pattern that correlates with sea surface temperatures that vary by latitude and time of year (Hay 1985). In considering the potential influence of spawn timing, evidence also suggests that herring abundance at least partially mediates the duration of spawn resource availability to coastal ecosystems. Although Pacific herring spawning events may occur once per year in a given area, herring are also known to spawn in waves, with between-spawn periods lasting up to 26 d (Salish Sea; Ware \& Tanasichuk 1989). Further, spawning is thought to be more drawn out in years with larger Pacific herring populations (Ware \& Tanasichuk 1989). Given that eggs from single spawning events in Quatsino sound persisted in intertidal and supratidal zones for at least $5 \mathrm{wk}$ (Fox 2013), evidence of greater deep-time herring abundances and distributional consistency (e.g. McKechnie et al. 2014) suggests that spawning events provided a wide range of coastal taxa, from primary producers to mammalian and avian predators, more prolonged and more widely distributed access to spawn resources in the past.

Waves of spawning activity still occur, at least in some locations (e.g. eastern Vancouver Island; C.H. Fox pers. obs.). Although some populations in BC are considered relatively healthy in terms of benchmarks set during the mid-20th century (e.g. 'aggregate Strait of Georgia stock'), longstanding low biomass and closed commercial fisheries characterize large regions of BC (Fisheries and Oceans Canada 2016). Unfortunately, these population declines and recovery failures are not limited to BC (e.g. Hay et al. 2001, Landis et al. 2004). Further, just as the reasons for these declines and recovery failures remain very 
poorly understood from scientific perspectives (e.g. Schweigert et al. 2010), the ecological consequences of reduced herring abundances, and in turn, the diminished delivery of spawning resources to coastal ecosystems, are poorly known. Despite the paucity of empirical evidence regarding ecological consequences, herring are a cornerstone species in coastal ecosystems along the Pacific coast of North America (Willson et al. 1998); herring population declines and recovery failures should be presumed to influence reliant primary producers and consumers of herring resources within linked marine, intertidal, and terrestrial ecosystems, including species of conservation concern.

Subject to often intense exploitation over the past 2 centuries (Hay et al. 2001, Beamish et al. 2004), herring populations and their distributions are unsurprisingly changed in comparison with past states (e.g. McKechnie et al. 2014). Subject to discretionary decision-making that may or may not adhere to management recommendations (e.g. Mandamin 2014, Manson 2015), federal fisheries management approaches regarding Pacific herring in $\mathrm{BC}$ are overdue for improvement. Following federal fisheries management conflict with several First Nations (e.g. Mandamin 2014, Manson 2015, Fox et al. 2016), a signaled shift towards co-management and development of a national Sustainable Fisheries Framework (Fisheries and Oceans Canada 2016) represents a rare opportunity for change. However, it remains to be demonstrated how and if broader socioecological perspectives on forage fish, coastal ecosystem considerations (including nearshore, intertidal, and terrestrial ecosystems), and local and Indigenous knowledge will be meaningfully incorporated.

The ecosystems along the Pacific coast of North America receive a diversity of pulsed and persistent spatial subsidies. Greatly informed by research into salmon-driven spatial subsidies, herring spatial subsidy research shares an unfortunate commonality; herring and salmon populations have both experienced significant population declines, distributional contractions, and/or recovery failures, with resultant diminished ecological consequences for the spatial subsidies they provide. Although biased by the shifting baseline syndrome (Pauly 1995), our study nonetheless provides further evidence of the broad ecological influence of Pacific herring on nearshore and intertidal ecosystems, and identifies multiple macrophyte and invertebrate species as receivers of herring-derived nutrients at spawning events. As a spatial subsidy, herring-derived resources appear to enter the food web at multiple trophic levels ranging from primary producers through to upper trophic level mammalian and avian predators. Combined with existing knowledge, evidence suggests that the delivery of herring spawning resources has declined both spatially and temporally, yet many, if not most, of the ecological consequences of these connections and the ramifications of their loss remain to be explored.

Acknowledgements. We thank 3 anonymous reviewers for their contributions to this manuscript. C.H.F. completed this research as part of a $\mathrm{PhD}$ program in the Department of Biology at the University of Victoria and was supported by a Natural Sciences and Engineering Research Council (NSERC) Postgraduate Scholarship and later a Killam Postdoctoral Fellowship in the Department of Oceanography at Dalhousie University. Research was partially supported by an NSERC grant to T.E.R. (grant NRC2354) and Raincoast Conservation Foundation. M. Adams, R. Davey, M. Fournier, M. Hall, K. Kezes, S. Rogers, and others are acknowledged for their contributions to this project. We also thank the Quatsino First Nation for permission to undertake this study in their traditional territory.

\section{LITERATURE CITED}

Alderdice DF, Velsen FPJ (1971) Some effects of salinity and temperature on early development of Pacific herring (Clupea pallasi). J Fish Res Board Can 28:1545-1562

Batschelet E (1981) Circular statistics in biology. Academic Press, New York, NY

*Beamish RJ, Benson AJ, Sweeting RM, Neville CM (2004) Regimes and the history of the major fisheries off Canada's west coast. Prog Oceanogr 60:355-385

* Ben-David M, Hanley TA, Klein DR, Schell DM (1997) Seasonal changes in diets of coastal and riverine mink: the role of spawning Pacific salmon. Can J Zool 75:803-811

Bishop MA, Green SP (2001) Predation on Pacific herring (Clupea pallasi) spawn by birds in Prince William Sound, Alaska. Fish Oceanogr 10:149-158

K Cederholm CJ, Kunze MD, Murota T, Sibatani A (1999) Pacific salmon carcasses: essential contributions of nutrients and energy for aquatic and terrestrial ecosystems. Fish Mag 24:6-15

* Christie KS, Reimchen TE (2008) Presence of salmon increases passerine density on Pacific Northwest streams. Auk 125:51-59

Cury PM, Boyd IL, Bonhommeau S, Anker-Nilssen T and others (2011) Global seabird response to forage fish depletion - one-third for the birds. Science 334:1703-1706

WDalton CM, Ellis D, Post DM (2009) The impact of doublecrested cormorant (Phalacrocorax auritus) predation on anadromous alewife (Alosa pseudoharengus) in southcentral Connecticut, USA. Can J Fish Aquat Sci 66: $177-186$

* Darimont CT, Reimchen TE, Paquet PC (2003) Foraging behaviour by gray wolves on salmon streams in coastal British Columbia. Can J Zool 81:349-353

Darimont CT, Paquet PC, Reimchen TE (2008) Spawning salmon disrupt trophic coupling between wolves and ungulate prey in coastal British Columbia. BMC Ecol 8:14

DeNiro MJ, Epstein S (1981) Influence of diet on the distri- 
bution of nitrogen isotopes in animals. Geochim Cosmochim Acta 45:341-351

Fisheries and Oceans Canada (2012) Stock assessment report on Pacific herring in British Columbia in 2012. Science Advisory Report 2012/062. DFO Canadian Science Advisory Secretariat, Pacific Region

Fisheries and Oceans Canada (2016) Pacific region integrated fisheries management plan, Pacific herring, November 7, 2016 to November 6, 2017. Government of Canada, Pacific Region

Foley MM, Koch PL (2010) Correlation between allochthonous subsidy input and isotopic variability in the giant kelp Macrocystis pyrifera in central California, USA. Mar Ecol Prog Ser 409:41-50

Fox CH (2013) Pacific herring and salmon: ecological interactions across the land-sea Interface. PhD dissertation, University of Victoria

FFox CH, Paquet PC, Reimchen TE (2010) Active American black bear dens adjacent to a marine beach used for foraging. Ursus 21:195-197

Fox CH, El-Sabaawi R, Paquet PC, Reimchen TE (2014) Pacific herring Clupea pallasii and wrack macrophytes subsidize semi-terrestrial detritivores. Mar Ecol Prog Ser 495:49-64

Fox CH, Paquet PC, Reimchen TE (2015) Novel species interactions: American black bears respond to Pacific herring spawn. BMC Ecol 15:14

Fox CH, Jacob AL, Darimont CT, Paquet PC (2016) Pacific herring and fisheries management in Canada: a new era or repeated history? Ocean Coast Manag 125:47-48

Fry B, Arnold C (1982) Rapid ${ }^{13} \mathrm{C} /{ }^{12} \mathrm{C}$ turnover during growth of brown shrimp (Penaeus aztecus). Oecologia 54:200-204

Fuiman LA, Connelly TL, Lowerre-Barbieri SK, McClelland JW (2015) Egg boons: central components of marine fatty acid food webs. Ecology 96:362-372

Fujita RM, Wheeler PA, Edwards RL (1989) Assessment of macroalgal nitrogen limitation in a seasonal upwelling region. Mar Ecol Prog Ser 53:293-303

Garman GC, Macko SA (1998) Contribution of marinederived organic matter to an Atlantic coast, freshwater, tidal stream by anadromous clupeid fishes. J N Am Benthol Soc 17:277-285

Haegele CW, Schweigert JF (1985) Distribution and characteristics of herring spawning grounds and description of spawning behavior. Can J Fish Aquat Sci 42(S1):s39-s55

Haegele CW, Humphreys RD, Hourston AS (1981) Distribution of eggs by depth and vegetation type in Pacific herring (Clupea harengus pallasi) spawnings in southern British Columbia. Can J Fish Aquat Sci 38:381-386

Hart JL, Tester AL, Beall D, Tully JP (1940) Proximate analysis of British Columbia herring in relation to season and condition factor. J Fish Res Board Can 4:478-490

Hay DE (1985) Reproductive biology of Pacific herring (Clupea harengus pallasi). Can J Fish Aquat Sci 42(S1): s111-s126

Hay DE, Toresen R, Stephenson R, Thompson M and others (2001) Taking stock: an inventory and review of world herring stocks in 2000. In: Funk F, Blackburn J, Hay D, Paul AJ, Stephenson R, Toresen R, Witherell D (eds) Herring: expectations for a new millennium. University of Alaska, Fairbanks, AK, p 381-454

Hepburn CD, Holborow JD, Wing SR, Frew RD, Hurd CL (2007) Exposure to waves enhances the growth rate and nitrogen status of the giant kelp Macrocystis pyrifera.
Mar Ecol Prog Ser 339:99-108

* Hobson KA (1999) Tracing origins and migration of wildlife using stable isotopes: a review. Oecologia 120:314-326

*Hocking MD, Reynolds JD (2011) Impacts of salmon on riparian plant diversity. Science 331:1609-1612

* Huynh MD, Kitts DD, Hu C, Trites AW (2007) Comparison of fatty acid profiles of spawning and non-spawning Pacific herring, Clupea harengus pallasi. Comp Biochem Physiol B 146:504-511

Iwasaki M, Harada R (1985) Proximate and amino acid composition of the roe and muscle of selected marine species. J Food Sci 50:1585-1587

Jahncke J, Checkley DM, Hunt GL (2004) Trends in carbon flux to seabirds in the Peruvian upwelling system: effects of wind and fisheries on population regulation. Fish Oceanogr 13:208-223

* Janetski DJ, Chaloner DT, Tiegs SD, Lamberti GA (2009) Pacific salmon effects on stream ecosystems: a quantitative synthesis. Oecologia 159:583-595

Keeling B, Hessing-Lewis M, Housty C, Okamoto DK, Gregr EJ, Salomon AK (2017) Factors driving spatial variation in egg survival of an ecologically and culturally important forage fish. Aquat Conserv 27:814-827

Kuribayashi T, Abe T, Montani S (2017) Historical $\delta^{15} \mathrm{~N}$ records of Saccharina specimens from oligotrophic waters of Japan Sea (Hokkaido). PLOS ONE 12:e0180760

* Landis WG, Duncan PB, Hayes EH, Markiewicz AJ, Thomas JF (2004) A regional retrospective assessment of the potential stressors causing the decline of the Cherry Point Pacific herring run. Hum Ecol Risk Assess 10: 271-297

ㄴ. Larsen T, Ventura M, Andersen N, O'Brien DM, Piatkowski U, McCarthy MD (2013) Tracing carbon sources through aquatic and terrestrial food webs using amino acid stable isotope fingerprinting. PLOS ONE 8:e73441

Mandamin LS (2014) The Ahousaht, Ehattesaht, Hesquiaht, Mowachaht/Muchalaht and Tla-o-qui-aht Indian Bands and Nations and Minister of Fisheries and Oceans. Federal Court, Docket T-404-14, Citation 2014 FC 197, Ottawa, p 1-16

Manson MD (2015) Federal Court, between the Council of the Haida Nation and Peter Lantin, Suing on Behalf of All Citizens of the Haida Nation (Applicants) and Minister of Fisheries and Oceans (Respondent). Federal Court, Docket T-73e15, Citation 2015 FC 290, Vancouver, p 1-22

Mathewson DD, Hocking MD, Reimchen TE (2003) Nitrogen uptake in riparian plant communities across a sharp ecological boundary of salmon density. BMC Ecol 3:4

McKechnie I, Lepofsky D, Moss ML, Butler VL and others (2014) Archaeological data provide alternative hypotheses on Pacific herring (Clupea pallasii) distribution, abundance, and variability. Proc Natl Acad Sci USA 111: E807-E816

* Minagawa M, Wada E (1984) Stepwise enrichment of ${ }^{15} \mathrm{~N}$ along food chains: further evidence and the relation between ${ }^{15} \mathrm{~N}$ and animal age. Geochim Cosmochim Acta 48:1135-1140

Moss ML (2016) The nutritional value of Pacific herring: an ancient cultural keystone species on the Northwest Coast of North America. J Archaeol Sci 5:649-655

*Pauly D (1995) Anecdotes and the shifting baseline syndrome of fisheries. Trends Ecol Evol 10:430

* Peterson BJ, Fry B (1987) Stable isotopes in ecosystem studies. Annu Rev Ecol Syst 18:293-320

Pikitch E, Boersma PD, Boyd IL, Conover DO and others 
(2012) Little fish, big impact: managing a crucial link in ocean food webs. Lenfest Ocean Program, Washington, DC

* Pikitch EK, Rountos KJ, Essington TE, Santora C and others (2014) The global contribution of forage fish to marine fisheries and ecosystems. Fish Fish 15:43-64

Polis GA, Anderson WB, Holt RD (1997) Toward an integration of landscape and food web ecology: the dynamics of spatially subsidized food webs. Annu Rev Ecol Evol Syst 28:289-316

Post DM, Layman CA, Arrington DA, Takimoto G, Quattrochi J, Montana CG (2007) Getting to the fat of the matter: models, methods and assumptions for dealing with lipids in stable isotope analyses. Oecologia 152:179-189

Purcell JE (1989) Predation on fish larvae and eggs by the hydromedusa Aequorea victoria at a herring spawning ground in British Columbia. Can J Fish Aquat Sci 46: 1415-1427

Reimchen TE (2000) Some ecological and evolutionary aspects of bear-salmon interactions in coastal British Columbia. Can J Zool 78:448-457

Reimchen TE (2018) Diverse ecological pathways of salmon nutrients through an intact marine-terrestrial interface. Can Field Nat 131:350-368

Reimchen TE, Fox CH (2013) Fine-scale spatiotemporal influences of salmon on growth and nitrogen signatures of Sitka spruce tree rings. BMC Ecol 13:38

Reimchen TE, Mathewson DD, Hocking MD, Moran J, Harris D (2003) Isotopic evidence for enrichment of salmonderived nutrients in vegetation, soil, and insects in riparian zones in coastal British Columbia. Am Fish Soc Symp 34:59-69

Restani M, Harmata AR, Madden EM (2000) Numerical and functional responses of migrant bald eagles exploiting a seasonally concentrated food source. Condor 102:561-568

Røttingen I (1990) A review of variability in the distribution and abundance of Norwegian spring spawning herring and Barents Sea capelin. Polar Res 8:33-42

Rounick JS, Winterbourn MJ (1986) Stable carbon isotopes and carbon flow in ecosystems. Bioscience 36:171-177

Schmidt SN, Olden JD, Solomon CT, Zanden M (2007) Quantitative approaches to the analysis of stable isotope food web data. Ecology 88:2793-2802

Schweigert JF, Boldt JL, Flostrand L, Cleary JS (2010) A review of factors limiting recovery of Pacific herring stocks in Canada. ICES J Mar Sci 67:1903-1913

Shelton AO, Francis TB, Williams GD, Feist B, Stick K, Levin PS (2014) Habitat limitation and spatial variation in Pacific herring egg survival. Mar Ecol Prog Ser 514: 231-245

Editorial responsibility: Steven Morgan, Bodega Bay, California, USA
Smith $\mathrm{AD}$, Brown CJ, Bulman CM, Fulton EA and others (2011) Impacts of fishing low-trophic level species on marine ecosystems. Science 333:1147-1150

Soulé ME, Estes JA, Berger J, Del Rio CM (2003) Ecological effectiveness: conservation goals for interactive species. Conserv Biol 17:1238-1250

Taylor FCH (1964) Life history and present status of British Columbia herring stocks. Bull Fish Res Board Can 143: $1-81$

* Thornton TF, Kitka H (2015) An indigenous model of a contested Pacific Herring fishery in Sitka, Alaska. Int J Appl Geospatial Res 6:94-117

*van Deurs M, Persson A, Lindegren M, Jacobsen C, Neuenfeldt S, Jørgensen C, Nilsson PA (2016) Marine ecosystem connectivity mediated by migrant-resident interactions and the concomitant cross-system flux of lipids. Ecol Evol 6:4076-4087

*Vander Zanden MJ, Clayton MK, Moody EK, Solomon CT, Weidel BC (2015) Stable isotope turnover and half-life in animal tissues: a literature synthesis. PLOS ONE 10: e0116182

*Varpe $\varnothing$, Fiksen $\varnothing$, Slotte A (2005) Meta-ecosystems and biological energy transport from ocean to coast: the ecological importance of herring migration. Oecologia 146: 443-451

*Verspoor JJ, Braun DC, Stubbs MM, Reynolds JD (2011) Persistent ecological effects of a salmon-derived nutrient pulse on stream invertebrate communities. Ecosphere 2: art18

* Wailes GH (1936) Food of Clupea pallasii in southern British Columbia waters. J Biol Board Can 1:477-487

*Walters AW, Barnes RT, Post DM (2009) Anadromous alewives (Alosa pseudoharengus) contribute marinederived nutrients to coastal stream food webs. Can J Fish Aquat Sci 66:439-448

*Ware BM, Tanasichuk WW (1989) Biological basis of maturation and spawning waves in Pacific herring (Clupea harengus pallasi). Can J Fish Aquat Sci 46:1776-1784

Willson MF, Womble JN (2006) Vertebrate exploitation of pulsed marine prey: a review and the example of spawning herring. Rev Fish Biol Fish 16:183-200

Willson MF, Gende SM, Marston BH (1998) Fishes and the forest. Bioscience 48:455-462

*Yang LH, Bastow JL, Spence KO, Wright AN (2008) What can we learn from resource pulses? Ecology 89: 621-634

Kimmerman RC, Robertson DL (1985) Effects of El Niño on local hydrography and growth of the giant kelp, Macrocystis pyrifera, at Santa Catalina Island, California. Limnol Oceanogr 30:1298-1302

Submitted: July 19, 2017; Accepted: March 3, 2017

Proofs received from author(s): April 24, 2018 